\title{
Membangun Karir Personal Branding Pasca Ajang Kontes Pria International (Studi Terhadap Mister International Indonesia 2015)
}

\author{
Reynaldi Rifaldo, Riris Loisa, Nigar Pandrianto \\ reynaldirifaldo98@gmail.com,ririsl@fikom.untar.ac.id,nigarp@fikom.untar.ac.id
}

Fakultas Ilmu Komunikasi Universitas Tarumanagara

\begin{abstract}
This study discusses a pageant actor who developed a career after an international event competition. Many pageants do not realize that they have potential and end up blaming themselves. However, there are some pageant actors who have succeeded in developing their careers. The purpose of this study is to find out the concepts of personal branding in the career of a pageant actor after his return to defend Indonesia. The subject of this research was Mister Internasional Indonesia 2015 and the object of this study was personal branding. This study uses a qualitative research approach with phenomenological methods and descriptive analysis. This study concludes that personal branding of international pageant actors in this study, begins with self-mapping and setting career goals after international competition. Good self-mapping, clear goals, and self-introspection are believed to produce good quality in his career. The initial process in personal branding is based on the principle of persistence, which is unique in building good personal branding in career and life development.
\end{abstract}

Keywords: career, influence, pageant actor, personal branding.

\begin{abstract}
Abstrak
Penelitian ini membahas mengenai seorang pelaku pageant yang mengembangkan karir pasca kompetisi ajang internasional. Banyak pelaku pageant yang tidak menyadari bahwa dirinya mempunyai potensi dan berakhir dengan menyalahkan diri sendiri. Namun demikian, ada beberapa pelaku pageant yang berhasil mengembangkan karir mereka. Tujuan dari penelitian ini ialah untuk mengetahui konsep-konsep personal branding dalam karir seorang pelaku pageant setelah kepulangannya membela Indonesia. Subjek dari penelitian ini adalah Mister Internasional Indonesia 2015 dan objek penelitian ini adalah personal branding. Penelitian ini menggunakan pendekatan penelitian kualitatif dengan metode fenomenologi dan analisis secara deskriptif. Penelitian ini menyimpulkan bahwa personal branding pelaku pageant internasional dalam penelitian ini, diawali dengan pemetaan diri dan menetapkan tujuan karir pasca kompetisi ajang internasional. Pemetaan diri yang baik, tujuan yang jelas, dan intropeksi diri diyakini akan menghasilkan kualitas yang baik dalam perjalanan karirnya. Proses awal dalam personal branding ini didasari prinsip persistensi, yang menjadi keunikan dalam membangun personal branding yang baik di dalam pengembangan karir dan kehidupan.
\end{abstract}

Kata Kunci: karir, menginspirasi, personal branding, pelaku pageant.

\section{Pendahuluan}

Kontes yang terkenal dalam bahasanya yaitu pageant yang sangat dikenal dengan sebutan kontes kecantikan yang identik dengan perempuan cantik memakai mahkota serta selempang dengan lambaian tangan yang khas. Pageant sudah dikenal sejak zaman Yunani Kuno, History Channel mengatakan bahwa kontes kecantikan pertama kali diadakan di Belgia bernama Spa pada tahun 1888 yang dimenangkan oleh Marthe Soucaret dari 349 kontestan lain, bisa dikatakan Marthe adalah ratu kecantikan 
pertama di dunia, yang mendapatkan kesempatan untuk tampil di sampul majalah Prancis L'Illustration. Lambat laun munculah sebuah kontes kecantikan bernama Miss America dengan tujuan menarik para turis di Atlantic City. https://www.rappler.com/indonesia/gaya-hidup/185581-kontroversi-dunia-pageantkontes-kecantikan di akses pada tanggal 4 November 2019 pukul 21:00.

Tidak hanya perempuan, di Indonesia pada era tahun 2000an sudah mulai bermunculan pageant untuk pria yang saat ini bisa dikatakan sebagai male pageant meskipun belum mendapatkan perhatian yang baik layaknya female pageant. Pageant berbeda dengan kontes bodybuilding, pageant sangat menilai dari segi kepribadian seseorang. Jika kontes perempuan identik dengan 3B: brain, beauty, dan behavior, kini untuk pria mempunyai 5B yaitu Brain, Beauty, Behavior, Brave and Believe. Seorang pria bukan hanya dilihat dari kecerdasan, ketampanan dan tingkah lakunya saja, melainkan dari keberanian dan bagaimana orang ini dapat dipercayakan dalam memegang sebuah gelar. Wajah pria yang tampan adalah syarat mutlak selain tubuh yang atletis dan wawasan yang luas. Alan merupakan orang yang berada di balik perhotelan Mister Singapore dan Mister Internasional yang saat ini menjadi kontes pemilihan pria terbesar di dunia selain Manhunt International, Mister World dan Mister Global. Alan juga sempat menghadiri pemilihan grand final L-men of the Year 2013 dimana pemenang tersebut akan mewakili Indonesia untuk mengikuti Mister International. Ajang pencarian ini juga berlangsung di Jakarta dan Bali, menjadi kedua kali bagi Indonesia setelah tahun 2010 menjadi host untuk pertama kalinya.

Jika sebelumnya wajah tampan dan pintar saja cukup, kini lebih banyak kriteria yang perlu dipenuhi oleh seseorang tersebut demi mendapatkan gelar juara melihat semakin tahun semakin berkembang dan bertambahnya para pelaku pageant yang semakin berkualitas dan mempunyai jiwa kompetitif yang sangat tinggi. Oleh karena itu, sebelum mendaftarkan diri sebagai kontestan, para calon harus mempersiapkan diri dengan keras. Pelaku male pageant harus mempunyai keberanian yang tinggi untuk menjalani semua tantangan sebagai public figure dan dipandang oleh banyak orang secara baik maupun tidak baik. Believe dimana saat pelaku male pageant akan menjabat selama setahun, pelaku pageant dapat dipercayai untuk melakukan kerja sama selama setahun dan menjalankan semua advokasi demi menjalankan sebuah tujuan dari advokasi male pageant tersebut.

Jika penelitian ini tidak dilaksanakan, dikhawatirkan akan mengakibatkan keambiguitasan dan kebingungan dalam sebuah proses yang terjadi dalam personal branding seseorang. Oleh karena itu, dengan adanya kegiatan penelitian ini diharapkan dapat membuka pikiran seseorang dalam mencapai tujuan sebuah personal branding dan dapat diterima dalam dunia karir seorang entertain serta paham dan mengerti apa yang seharusnya dilakukan dan yang tidak seharusnya dilakukan demi mencapai keberhasilan dalam sebuah promosi diri.

\section{Metode Penelitian}

Pada penelitian ini, peneliti menggunakan pendekatan secara kualitatif dengan metode fenomenologi dan penyajian analisis secara deskriptif. Menurut Kriyantono (2010) Riset Kualitatif bertujuan untuk menjelaskan sebuah peristiwa dengan pengumpulan data sedalam dalamnya. Riset ini tidak dilakukan secara kuantitatif dikarenakan penelitian ini dinilai dari sebuah kegiatan secara subjektif. Penelitian ini tidak mengutamakan besarnya sebuah populasi atau sampling lainnya. Jika data yang terkumpul sudah lengkap dan mendalam dan bisa menjelaskan fenomena yang diteliti, 
maka tidak diperlukan untuk mencari sampling lainnya. Penelitian ini berusaha untuk menggambarkan keadaan yang sesungguhnya mengenai personal branding yang dapat membangun karir seseorang di Indonesia pasca mengikuti ajang male pageant internasional. Proses pengambilan dan pengumpulan data dilakukan dengan cara observasi, wawancara, dan internet searching secara mendalam dengan seorang Mister International Indonesia 2015 sebagai subjek penelitian serta melakukan beberapa dokumentasi agar peneliti dapat menulis dan menganalisis.

Jenis penelitian ini adalah penelitian secara deskriptif. Menurut Whitney dalam Mohammad Nazir mengatakan bahwa metode deskriptif adalah pencarian sebuah fakta dengan interpretasi yang akurat dan tepat. Penelitian deskriptif mempelajari tentang masalah-masalah dalam masyarakat, tata cara yang berlaku dalam masyarakat serta situasi-situasi tertentu, termasuk tentang proses-proses, sikap-sikap, kegiatankegiatan, pandangan-pandangan, serta hubungan-hubungan yang sedang berlangsung dari suatu fenomena. Peneliti menggunakan metode fenomenologi yang berfungsi untuk menjawab pertanyaan dari penelitian yang berkaitan dengan proses pembentukan personal branding pasca ajang kontes Mister International. Fenomenologi merupakan pendekatan yang mempelajari tentang beberapa peristiwa yang saling berkaitan dan dipelajari secara mendalam untuk memahami dan mengerti dari peristiwa tersebut secara jelas dan mendalam.

Penelitian yang menggunakan penelitian fenomenologi mampu menggambarkan arti dan pengalaman hidup tentang orang tersebut dari sebuah konsep atau fenomena. Orang-orang yang terlibat menghadapi sebuah fenomena atau peristiwa melakukan eksplorasi terhadap struktur kesadaran pengalaman hidup. Pendekatan kualitatif dengan metode fenomenologi untuk memperoleh hasil penelitian dengan gambaran serta penjelasan yang mendalam. Kajian fenomenologi yang dilakukan peneliti dalam penelitian ini untuk memahami bagaimana pengalaman talent mengenai proses pembangunan personal branding pasca kompetisi pria ajang internasional sehingga ditemukan struktur inti atau pusat di balik pengalaman responden terhadap suatu fenomena.

\section{Hasil Temuan dan Diskusi}

Menurut Haroen dalam Diah Ayu Candraningrum mengemukakan bahwa, branding adalah aktivitas yang bertujuan untuk membangun persepsi serta kepercayaan seseorang dan merupakan kebutuhan semua orang yang memiliki kepentingan untuk mendapatkan sesuatu dari orang lain melalui proses komunikasi. Penulis akan membahas dan menganalisis hasil penelitian berupa datang yang diperoleh dari hasil wawancara dengan beberapa narasumber yang berlokasi di Starbucks, AEON Mall City yang berdekatan dengan lokasi shooting Kenny Austin. Penulis sudah memperoleh hasil wawancara dari responden Mukie Muza di Starbucks Tebet Indah Square pada tanggal 13 November 2019, dalam menganalisis data, Peneliti menggunakan teori personal branding Rampersad (2006, 2007 ) yang terdiri dalam 11 konsep yaitu Otentik, Integritas, Konsistensi, Spesialisasi, Otoritas, Keistimewaan, Relevan, Visibilitas, Persistensi, Goodwill, dan kinerja. Di dalam penelitian ini, terdapat pihak yang yang dijadikan informan. Kenny Austin merupakan informan utama dalam penelitian ini. Peneliti ini juga menerima narasumber dari salah satu founder portal pageant pertama di Indonesia bernama Mukie Muza yang bertugas untuk mempublikasikan berita tentang pageant serta mempunyai latar belakang untuk memberikan pendapat yang berkaitan dengan penelitian ini. Kenny adalah salah satu 
public figure yang dapat dikatakan sukses dalam karirnya setelah kepulangannya di dalam dunia pageant di kancah International.

Dalam melakukan kegiatan nya di dunia maya, Kenny Austin hadir sebagai orang yang mempunyai ciri khas tersendiri. Kenny Austin merupakan seseorang yang sadar dengan kekurangan maupun kelebihan dirinya sendiri. Kenny paham atas dirinya yang bisa dikatakan mempunyai wajah yang berbeda dengan teman-temannya. Dapat dikatakan Kenny mempunyai wajah yang menggemaskan di usia dewasanya. Maka dari itu, Kenny memanfaatkan wajahnya yang menggemaskan dengan skill dalam dunia peran yang Kenny kembangkan. Akun @KennyAuztin dikenal sebagai akun yang tidak pernah mengumbar tentang kesehariannya, Kenny lebih mengekspresikan dirinya melalui Instagram dengan karya yang Kenny tunjukan dalam dunia akting sinetron maupun film. Kenny mengatakan sewaktu dulu ia mempunyai skill yang sangat rendah dalam memerankan sebuah karakter, tetapi Kenny tau goalsnya akan menjadi aktor, jadi ia lebih memperkaya ilmu-ilmu dengan menonton film-film luar dan mempelajari aktingnya. Apalagi drama Korea, Kenny sangat menyukainya karena penjiwaan karakternya yang sangat mendalami, dan Kenny sangat belajar dari aktoraktor Korea.

Fokus pada suatu bidang tertentu dan menguasai suatu bidang dalam satu hal akan membuat seseorang mempunyai kelebihan tersendiri di mata khalayak. Sehingga dalam pekerjaan yang Kenny Austin lakukan dalam memainkan peran menjadi seorang aktor sangatlah membutuhkan spesialisasi. Kenny Austin sangat mendalami perannya menjadi seseorang aktor yang dikenal sebagai anak yang menggemaskan. Dengan menyadari dirinya seperti itu, Kenny sangat menajamkan talentanya sebagai aktor dengan wajah oriental yang menggemaskan. Seperti yang dikatakan oleh Mukie. Kenny mengatakan bahwa bisa menjadi sekarang ini karena ia sadar akan kekurangan dan kelebihan yang ia miliki, maka dari itu ia memfokuskan kelebihannya dan berusaha menguasai dalam bidang tersebut menjadi spesialisasi Kenny.

Dalam membangun personal branding pada karir, ada kalanya orang tidak memberikan respon sama sekali. Hal tersebut terkadang membuat beberapa para pelaku pageant mundur perlahan hingga akhirnya dapat menghentikan mereka. Tidak mungkin orang yang baru dikenal dapat dipercayai begitu saja, tetapi melalui waktu masyarakat akan mengenal siapa orang itu. Ketika pertama kali Kenny mulai merantau ke Jakarta, Kenny bukanlah seorang anak yang bisa dikatakan berkecukupan dalam segi finansial. Kenny mengalami kekurangan sehingga harus meminta bantuan kepada orang tua dari segi finansial. Cuma hal itu tidak membuat Kenny patah semangat dalam mencari sebuah peluang dalam berkarir di Jakarta. Kenny terus konsisten melatih skill dengan sekolah akting, tekun dalam belajar akting dan juga terus menjalin relasi baik dengan para produser-produser hingga akhirnya Kenny mendapatkan penawaran film pertamanya.

Dalam membangun personal branding pada suatu karir, menjadi berbeda dari yang lain membuat dirinya menjadi suatu keunikan yang tidak dimiliki orang, dan hal ini dapat menarik perhatian masyarakat. Menjadi seseorang yang sama dengan pelaku pageant lainnya, tidak membuat orang dikenal dengan ciri khasnya. Kenny Austin juga mempunyai peran yang bisa dikatakan sesuai dengan karakter dan wajah yang Kenny mainkan, sehingga banyak sekali penggemar yang menyukai peran Kenny. Kenny terlihat mempunyai skill yang sangat baik dan memiliki kenaturalan dalam seni peran. Dalam dunia akting yang Kenny mainkan, banyak sekali peran yang mewakili kehidupan para fans yang menontonnya. Kenny juga mengatakan peran yang ia 
mainkan juga dapat memengaruhi pamor para si pemain, jadi berhati-hati dalam menerima karakter jika ingin memainkan sebuah peran yang ditawarkan.

Kenny dikenal dengan orang yang tidak banyak bicara di sosial media, tetapi lebih aktif jika bertemu tatap muka dengannya. Kenny sangat selektif dalam memerankan sebuah skenario sinetron atau pun film yang akan Kenny jalankan, karena peran yang Kenny mainkan akan mengarah kepada kehidupan dan personal branding Kenny di depan masyarakat. Dalam memerankan sebuah karakter, Kenny sangatlah mendapatkan dukungan dan keantusiasan yang tinggi. Kenny selalu dikenal dengan pemuda yang tampan, aktif dan juga ramah kepada siapapun.

Seseorang yang dipandang secara positif oleh khalayak akan lebih bertahan lama dengan personal brand yang sudah dimilikinya. Pandangan positif yang datang dari khalayak tersebut tidak datang dengan sendirinya, melainkan dari nilai-nilai yang sudah ditanamkan oleh pelaku personal branding dengan cara tetap memberikan informasi yang positif di media sosial maupun sinetron yang ia perankan dalam sinetron SCTV. Kenny mengatakan bahwa dalam memilih peran, ia juga harus pintarpintar memilih karakter yang akan ia mainkan, karena karakter itu dapat mempengaruhi pamor dari seseorang tersebut. Penonton akan menilai diri seseorang tersebut dengan karakter yang akan dimainkan. Kenny berbagi pengalamannya dengan menceritakan temannya yang mendapatkan karakter antagonis, dan pada suatu saat seorang temannya tersebut sedang berjalan di Mall, banyak sekali yang terbawa perasaannya dan temannya tersebut dikenal dengan karakternya yang jahat.

Pelaku personal branding harus mendistribusikan pesannya secara berulangulang, terus menerus dan konsisten hingga hal tersebut tertanam dalam benak audiens. Pesan-pesan yang selalu diulangnya, kemudian menimbulkan banyak komentar di kolom komentar Instagram. Para followers Kenny yang sangat menyukainya, semakin menjadi suka karena disuguhi informasi apapun seputar Kenny Austin setiap harinya. Informasi yang diberikan oleh Kenny bukan berarti yang diberikan adalah informasi yang intens, melainkan keadaan Kenny yang seadanya dan jarang memberikan informasi yang sangat lengkap seperti para artis lainnya yang memberikan informasi pada instastories di Instagram dengan lengkap. Dengan itu, para followers sudah terbiasa dengan karakter Kenny yang seperti itu.

Mukie mengatakan bahwa pemenang tidak dimenangkan begitu saja dengan mudah, tapi pasti akan ada situasi dimana para dewan juri yang berdiskusi menimbulkan perkelahian pendapat untuk menentukan seorang pemenang. Mereka juga memikirkan potensi jika seorang pemenang tersebut dapat bekerja dan memenuhi kriteria yang juri inginkan. Di saat juri memenangkan, juri memenangkan yang berpotensi, setelah itu akan mudah untuk dilatih. Seseorang pelaku pageant yang dimenangkan bukan berarti orang itu yang paling hebat, melainkan ia adalah orang yang punya potensi sesuai advokasi yang diinginkan oleh organisasi. Mukie mengatakan jangan menyalahkan organisasinya jika anak-anaknya tidak sukses, karena semua tergantung seorang pelaku pageant tersebut, apakah pemetaan yang ia lakukan sesuai dengan kriteria atau tidak.

Seseorang yang dimenangkan oleh sebuah organisasi dan diberikan kesempatan untuk bersaing di International adalah suatu kesempatan atau ajang bukan untuk menyampaikan ketenarannya. Tetapi ajang untuk belajar dan menerima budaya luar untuk mewakili Indonesia tercinta. Jadi, jika sepulangnya International sudah menjadi lupa diri, pelaku tersebut harus mengetahui pemetaan diri serta menyesuaikan diri kemana saja arah yang cocok untuk dirinya. Seseorang yang sepulangnya 
kompetisi Internasional tidak selalu harus bekerja dan sukses dalam dunia entertainment, tetapi bisa juga di dalam dunia yang lain.

Mukie mengatakan bahwa ketenaran atau kesuksesan bukan dilihat dari jumlah banyaknya followers, tetapi balik lagi kepada tujuan dari pandangan seorang pelaku pageant sebanyak apa para pelaku mempengaruhi para pengikutnya ke arah yang lebih baik. Mukie mengatakan bahwa kesuksesan dari seorang pelaku pageant bukan dilihat dari jumlah banyaknya followers, tapi sebanyak apa mereka mempengaruhi orang ke arah yang lebih baik, Kenny kalau dari pandangan pageant, masih banyak selain Kenny yang lebih hebat dalam meng influence orang, tapi jika dari segi karir dari pandangan yang Kenny inginkan sendiri, Kenny sudah mencapai kesuksesan dalam karirnya. Jadi dari segi pandang pageant dan dirinya sendiri dalam karir seorang aktor yang berbeda, karena kesuksesan orang diukur dengan standar yang berbeda-beda.

\section{Simpulan}

Berdasarkan hasil pembahasan mengenai pembentukan personal branding Kenny Austin mengenai karirnya pasca ajang kontes pria international ( Studi terhadap Mister International Indonesia 2015), Kenny Austin membangun personal brandingnya berawal menjadi Mister International Indonesia 2015, kemudian mengembangkan dari 11 konsep dalam personal branding di televisi dan instagram.

11 konsep yang dilakukan oleh Kenny Austin adalah:

a. Otentik : Kenny Austin menyadari dirinya yang hanya sedikit saingannya dalam pasar berwajah oriental sehingga Kenny sangat percaya diri dengan karirnya.

b. Integritas : Kenny mempunyai tanggung jawab untuk menghibur para penggemarnya dan terus menonton aktor Korea serta membaca buku dari para senior yang berpengalaman seperti Reza Rahardian demi memperkuat ambisi dan kualitasnya.

c. Konsistensi : Kenny merupakan sosok yang dikenal mudah bergaul dan juga sudah dikatakan cukup lama dalam dunia acting sekitar 5 tahun, energi positif dan figur yang baik terus konsisten dipertahankan olehnya.

d. Spesialisasi : Kenny rela membanting setir ke dalam dunia perfilman demi menyambung hidup dan pada akhirnya seni peran menjadi keahlian Kenny dalam berkarir.

e. Otoritas : Walau Kenny terlihat sangat hebat dalam memainkan peran, tapi malah justru Kenny merasa ilmu yang ia miliki masih harus ditingkatkan dan dipertajam serta harus banyak belajar dengan para senior.

f. Keberbedaan : Kesadaran Kenny bahwa dirinya dikenal sebagai sosok lakilaki yang mempunyai wajah yang menggemaskan tidak membuat Kenny lemah, tetapi membuat itu menjadi sebuah kelebihan dan menjadikan kegemasannya menjadi sesuatu yang unik di depan masyarakat.

g. Relevan : Kenny disenangi oleh para fans karena Kenny sangat menggambarkan dirinya secara nyata tanpa penuh rekayasa ataupun drama dalam hidupnya.

h. Visibilitas : Secara tidak sadar Kenny menyebarkan informasi yang menyampaikan secara berulang-ulang bahwa dirinya mirip dengan artis-artis Korea yang sedang digemari oleh masyarakat Indonesia, sehingga informasi tersebut, Kenny terus mendapat pujian dari netizen. 
i. Persistensi : Walau Kenny jarang memposting kegiatan sehari-harinya melalui sosial media, namun dirinya sangat rajin sekali meningkatkan kualitas dirinya dengan membaca buku dan belajar acting.

j. Goodwill : Kenny selalu menyempatkan waktu jika dirinya libur shooting dengan berolahraga agar dirinya tetap sehat dan dapat terus bekerja sama dan bekerja dengan karir yang ia cintai sekarang.

k. Kinerja : Kenny mengatakan bahwa harus mencintai pekerjaannya terlebih dahulu, baru kita dapat bekerja dengan maksimal dan memperdalam pekerjaan dalam sebuah karir.

Karir pelaku pageant tersebut dapat dilihat dari berbagai pandangan sesuai dengan kebutuhan peneliti, tujuan dari pelaku pageant itu sendiri dan pemetaan diri. Jika dilihat dari segi karir, Kenny Austin sudah mencapai titik kesuksesannya dalam dunia peran sesuai dengan personal branding yang ia bangun dengan baik dan jelas. Tetapi jika dilihat dari segi tujuan advokasi seorang pageant, masih banyak pelaku pageant lain yang sangat kuat dengan melakukan tujuan dari advokasinya, sehingga tujuan dari pageant yaitu menginspirasi, Kenny belum mencapai titik maksimal dalam konteks tersebut.

\section{Ucapan Terima Kasih}

Peneliti mengucapkan terima kasih yang sebesar-besarnya kepada keluarga dan teman-teman yang telah memberikan bimbingan serta rekan-rekan yang telah membantu dalam proses penelitian ini.

\section{Daftar Pustaka}

Candraningrum, Diah.A. (2018). Teknologi Komunikasi Informasi Untuk Peningkatan Kesadaran Publik Pada Organisasi Sosial. Jurnal Komunikasi.

Haniy, Sakinah Umuh (2017) Memahami kontes kecantikan yang penuh kontoversi https://www.rappler.com/indonesia/gaya-hidup/185581-kontroversi-duniapageant-kontes-kecantikan

Kriyantono, Rakhmat. 2010. Teknik Riset Komunikasi. Kencana: Jakarta.

Rampersad, Hubert K (2008) Authentic Personal Branding-A new blueprint for building and aligning a powerful leadhership brand. Penerbit PPM Menteng Raya, Jakarta Pusat. 